\title{
'Living at the border of poverty': How theater actors maintain their calling through narrative identity work
}

\begin{abstract}
People who have a sense of calling to their work are more inspired, motivated and engaged with what they do. But how is calling constructed and maintained within organizations? More importantly, how do people maintain a sense of calling to their work when this is a source of ongoing material and existential hardships? This paper seeks to address these questions by looking at the artistic setting of theater where actors maintain their calling despite their precarious work situation. The study employs a narrative approach to illustrate how three dominant narratives — religious, political and therapeutic — are central in constructing theater work as deeply meaningful. Specifically, each narrative explains how theater actors maintain their calling through different processes of identity work enacted through sacrifice (religious), responsibility (political) and self-care (therapeutic), with corresponding role identities as martyrs (religious), citizens (political) and self-coaches (therapeutic). We contribute to the literature on callings by: (a) showing how different processes of identity work are central to maintaining callings in precarious work situations, (b) exploring the role played by the 'other' as an interlocutor in accounting for and maintaining callings, and (c) advancing a theoretical explanation of callings that illustrates how callings contingently emerge as acts of elevation, resistance or resilience within contemporary society.
\end{abstract}

Keywords: calling, hardships, identity work, narrative, other, theater. 
When defining an individual's work orientation, scholars have made analytical distinctions between jobs (focus on financial gains), careers (focus on career advancement) and callings (focus on 'deep' meaningful work) (Bellah et al., 1985; Wrzesniewski et al et al., 1997). Work viewed only as a job or career is unlikely to inspire deep meaning beyond instrumental or personal interests. On the other hand, a calling has personal, moral and social significance (Rosso et al., 2010). More than a means to an end, individuals who view their work as a calling are likely to perceive it as an end in itself, believing that 'their work contributes to the greater good and makes the world a better place' (Wrzesniewski, 2003: 301).

The conceptualization of work as a calling is important in organization and management theory due to its relationship to meaningful work (Bunderson and Thompson, 2009) and the ways it impacts organizational roles and identities (Berkelaar and Buzzanell, 2015). In business practice, pursuing a calling is increasingly encouraged, especially in liberal workplaces that emphasize innovation, authenticity and creativity as keys to success (Fleming, 2009). This interest in work as a calling can be seen as growing along with the spread of 'workplace spirituality' (Lips-Wiersma et al., 2009) as a means through which contemporary organizations strive for higher efficiency and productivity (Duffy et al., 2012). As such, investigating work as a calling assumes particular significance at a time when 'many people frame their careers as callings, and also expect callings to be enacted through their careers' (Berkelaar and Buzzanell, 2015: 171).

Within organization and management scholarship, callings have been conceptualized as 'sacred' or 'secular' (Steger et al., 2010), with a substantial focus on sources, means and outcomes (Dik and Shimizu, 2018) at the expense of how people construct and maintain callings (Duffy et al., 2012). The aim has been to identify the benefits associated with the enactment and pursuit of a calling (e.g., increased job performance (Kim et al., 2018), with part of the contemporary literature conceiving calling as depending upon inner drives toward 
self-interest and personal fulfilment (Hall and Chandler, 2005). This introspective and selffocused conceptualization of callings has raised two concerns. First, in emphasizing the benefits of callings, scholars and practitioners have paid less attention to its shortcomings (Berkelaar and Buzzanell, 2015; Duffy et al., 2016). For example, it has been demonstrated that people perceiving their work as a calling work more hours, regardless of compensation (Wrzesniewski, 2003), and may struggle with poverty, workaholism and exploitation (Duffy et al., 2016). Thus, callings may be more beneficial to organizations than to employees (Bell et al., 2012) and, therefore, it becomes crucial to examine how social actors maintain callings in the face of hardships (Duffy et al., 2012; Schabram and Maitlis, 2017).

Second, the centrality of the self at work in the calling literature is seen as diluting ethical and social implications by downplaying 'otherness', which is considered a crucial dimension of callings (Bunderson and Thompson, 2009). This criticism suggests that callings should be considered as such when they advance prosocial or other-oriented ends (e.g., God, societal needs) (Dik and Shimizu, 2018; Michaelson and Tosti-Kharas, 2019). Hence, in studying how people maintain calling in face of hardships, the role of the other is somewhat undertheorized.

In this inquiry we address this set of concerns-i.e., how people maintain calling in face of hardships and the role played by the other in this - by analyzing the narrative accounts of a group of theater actors who explicitly described their work as a "deep necessity" (i.e., a calling). The analysis reveals three overarching narratives-religious, political and therapeutic - prevalent in the theater context and employed by the actors in managing hardships and framing their engagement with the other. Each narrative structure explains how actors maintain their calling through forms of identity work enacted through sacrifice (religious), responsibility (political) and self-care (therapeutic), with corresponding role identities as martyrs (religious), citizens (political) and self-coaches (therapeutic). 
We make three contributions to the literature. First, whereas existing research emphasizes the source or basis of a calling, scholars have paid limited attention to how people 'normalize particular ways of being and thinking about career and calling' (Berkelhaar and Buzzanell, 2015: 172). We show that under precarious working conditions, actors maintain their calling through forms of narrative identity work. Importantly, the centrality of hardships in the narrative constructions of callings reveals a vulnerability to exploitation (Berkelhaar and Buzzanell, 2015). Second, we explore the duty towards the other-considered central in accounting for and maintaining a calling (Bunderson and Thompson, 2009) — and the distinct forms the other takes in the different narrative structures. Finally, we advance a theoretical explanation of callings that illustrates how callings contingently emerge as acts of elevation, resistance or resilience within contemporary society.

\section{Work as a personal calling}

Current conceptualizations of work as a calling are primarily rooted in the historical rationalities of the Protestant Reformation, which took place in a time of a 'rapidly expanding market economy, accelerated urbanization, technological innovation, and vast political organization' (Hardy, 1990: 65). Reformers such as Martin Luther and John Calvin resisted the view of the Catholic Church that protected the 'sacred' vocation of the elected few and replaced it with the 'secular' work of the masses (Dawson, 2005). In establishing a distinction between a 'vocation' and a 'calling', the Protestant tradition considered all paid work as having equal value while presenting an alternate path for human expression, self-fulfillment and salvation. According to Weber (1930: 24), in its classical definition 'a "calling" (Beruf) was given by God', it provided the person with a strong sense of self, and it functioned as a key drive of the self-work ethic of capitalism. The centrality of paid work as a way to serve God's will took a secular step during the Victorian age, when a modern definition of calling emerged that framed finding meaning to our existence as a personal obligation and duty (Baumeister, 1991). 
In contemporary Western society, individuals are encouraged to search for (and find) work that is not just a means to an end (i.e. money, career, social position, status), but an end in itself (i.e. work that serves as a 'source of significance' in providing inner or self-cultivation) (Heelas, 2002). In practice, training and development programs and performance appraisal systems are aimed at generating a sense of belonging and meaning for employees who do not view their work as a calling (Bardon et al., 2017). Within organization and management scholarship, this modern calling has been largely understood as something one does to accomplish personal happiness (Novak, 1996) or in the pursuit of a life goal that contributes to self-realization (Hall and Chandler, 2005) and self-expression (Wrzesniewski et al., 1997).

Despite the religious origins, the debate on work as a calling shows that religiosity is neither an obligatory nor sufficient element determining its existence (Hirschi, 2011). An individual may identify a calling via introspection, self-reflection or meditation (Elangovan et $a l ., 2010$ ), or in response to external commandments: 'A form of higher power, the needs of society, a family legacy, the needs of one's country, or any other force external to the individual' (Duffy and Dik, 2013: 429). As such, callings are not univocal (Hirschi, 2011); they may mean different things to different people, have different degrees of enactment, and change over time (Dik and Shimizu, 2018). However, the other-oriented aspect of a calling continues to be debated in the literature. Whilst some scholars see a calling as primarily fulfilling a sense of purpose in life (Hall and Chandler, 2005), others argue that a 'true' calling must be otheroriented or serve society (i.e. the work must be oriented as a duty towards others and have social or ethical purposes) (Wrzesniewski et al., 1997).

A growing neoclassical perspective within the literature problematizes the notion that a calling is all-encompassing (Bunderson and Thompson, 2009; Berkelaar and Buzzanell, 2015; Duffy et al., 2016). These studies help isolate three set of issues that we seek to address through our inquiry. First, by focusing primarily on the sources and means of calling, scholars 
have paid less attention to how people construct and maintain callings (Berkelaar and Buzzanell, 2015; Duffy et al., 2012). From a managerial perspective, such an imbalance is arguably connected to the need to identify the benefits of callings to organizations and employees. For example, in a study on counseling psychologists, Duffy et al. (2012) showed that support from others, flexible schedules, and accommodating administrators were keys to maintaining a calling. Wrzesniewski (2003: 304) suggested that an individual may proactively frame his or her work as a calling 'by reshaping the task and relational boundaries of the job in ways that allow one to view the work as making a bigger contribution to the wider world'. However, considering the contingent nature of callings, there is limited research on how people who perform similar work construct their callings differently, and how they adapt these constructions to situational circumstances.

The emphasis on benefits in the literature leads to a second set of concerns: the limited attention paid to the 'potential perils and pitfalls' of callings (Duffy et al., 2016: 634). When energy is invested in maintaining callings, individuals may experience 'conflicting emotions, self-doubt, externally imposed delays and...inter-role conflicts' (Madden et al., 2015: 867). Furthermore, individuals with callings may be exposed to burnout and workaholism (Cardador and Caza, 2012) and risk identity manipulation and exploitation to serve organizational goals (Berkelaar and Buzzanell, 2015). Individuals who view their work as a calling may simultaneously experience 'agony and ecstasy' (Petriglieri et al., 2017) due to the physical, psychological, material, and emotional costs of their pursuits (e.g. sacrificing leisure time, health, pay and/or career mobility) (Berkelaar and Buzzanell, 2015; Bunderson and Thompson, 2009). Nonetheless, it is unclear how individuals manage the hardships (e.g. work discontinuity) that create these personal costs (e.g. anxiety) in maintaining their callings.

The third set of issues relates to the role of the other in a calling, which was an imperative in the classical definition: 'The fulfilment of duty in vocational callings became 
viewed as the highest expression that moral activity could assume'; moreover, 'when one is called by God into a vocation, or a specific line of coherent work, that person is "duty-bound" to it' (Weber, 1930: 100). As Bunderson and Thompson (2009) outlined in their study on zookeepers, the neoclassical perspective supports this view in arguing that a calling should entail sacrifice for a higher purpose and a sense of duty to others (e.g. people, animals, the environment) undergirded by prosocial and other-oriented values (Wright et al., 2012). Hence, the concept of duty includes some form of otherness in its enactment. Dik and Duffy (2009: 427) viewed a calling as 'originating beyond the self', with 'other-oriented values and goals as primary sources of motivation'. Nonetheless, despite the centrality of the other in this perspective on work as a calling, little is known about how and to what extent the other plays a role in maintaining a calling and justifying its hardships.

At the intersection of these three concerns, we examine how people maintain their callings in the face of hardships and the role played by the other as an interlocutor in the callings. Specifically, we employ the analytical lens of narrative identity work to explore how a group of theater actors maintain their calling despite precarious work conditions.

\section{Narrative identity work and the importance of 'otherness' in calling}

A fruitful theoretical avenue to understand how actors - those in theater and more generallymake sense of and bring purpose to their work is the 'narrative turn' in organization and management scholarship (Czarniawska, 1998). This line of thinking proposes that narratives are the primary way individuals imbue experiences with meaning. Narratives are used to define who we are, and they endow social actors with identities by providing a person's life with some degree of coherence, purpose and meaning (Wright et al., 2012). Ricoeur (1984, 1991) articulated the notion of narrative identity, implying that the elements employed in the construction of narratives find the same applicability in the construction of identities. According to Ricoeur, these elements are 'emplotment' (i.e. the plot with characters that 
progresses in time) and 'mimesis' (i.e. the inability to access the 'real' meaning of a story, as one can only access meaning based on how the story is told). Mimesis allows for dramaturgical performance; by narrating their identities (Riessman, 2008), individuals make sense of the world they inhabit and their roles in it (Weick, 1985). Thus, narratives can be appreciated as devices through which individuals interpret and understand themselves and the social world as they temporally organize different life experiences and events into a story.

In conceiving narratives as constitutive of organizational realities (Van Maanen, 1988), organization and management researchers have addressed how people at work engage with cultural and institutional stories, or public narratives (Somers, 1994), when constructing selfnarratives (Clarke et al., 2009). Through narration, social actors negotiate and re-negotiate their identities, positioning themselves in relation to others to define who they are and are not (Bamberg, 2009). Narration is also an important means through which individuals navigate uncertainty and manage identity conflicts, a process captured by the notion of 'identity work'-i.e. the ongoing activity of 'forming, repairing, maintaining, strengthening or revising the constructions that are productive of a sense of coherence and distinctiveness' (Sveningsson and Alvesson, 2003: 1165).

Whilst identity construction is the broad process through which a person shapes his/her sense of self and identity, identity work is an ongoing process that encompasses people's active efforts to craft and maintain identities through language and practice via the interplay between self-identities and social identities (Brown, 2015; Watson, 2008). In addition to being agentic, identity work has a relational, dialogic and processual character (Beech 2008), and occurs when a meaningful existential tension triggers feelings of anxiety or insecurity. This tension needs to be mediated to achieve coherence and distinctiveness (Alvesson and Willmott, 2002). Notably, identity work is not only self-affirming, but can also be self-questioning, thereby 
keeping tensions alive. For example, artists experience tension between the 'craft' and the 'job' that is necessary to maintain a meaningful work identity (Beech et al., 2016).

Within the organization and management literature, identity work has been conceptualized foremost as a response to identity regulation: the ensemble of discursive practices concerned with identity definition that condition processes of identity formation and transformation' (Alvesson and Willmott, 2002: 627). Through different strategies of compliance, cynicism or humor, people may (dis-)identify with their organizations (Alvesson and Karreman, 2004; Huber and Brown, 2017) and constrain themselves by means of selfdiscipline (Thornborrow and Brown, 2009) to conform with or resist organizational prescriptions (Collinson, 2003). Through identity work, social actors also attempt to construct themselves as good and virtuous by assembling stories about themselves based on different narrative genres (Wright et al., 2012), reflecting upon their own life stories in relation to personal, organizational and societal issues (Watson, 2008), or re-authoring the self to incorporate antagonistic identities (Clarke et al., 2009). Importantly, an individual's narrative accounts expose the 'constructed and relational nature of what is seen as ethically and morally good' (Nyberg and Sveningsson, 2014: 440). Thus, examining narrative identity work is a valuable way to understand how social actors make sense of and structure their lives relative to organizational phenomena, which, in our case, is how they maintain a calling.

\section{Research setting and methods}

We employ a narrative approach to examine how theater actors maintain a calling despite the hardships of their precarious and creative work. Narratives play a constitutive role in identity formation and the expression of value judgments and choices (Bamberg, 2009). As Bruner (1994: 53) put it, 'we become who we are through telling stories about our lives and living the stories we tell'. Although analytical distinctions have been made between the concepts of 
'narrative' and 'story' (Boje, 2011), we treat them as synonymous (Riessman, 2008) and understand them to be simultaneously organizational and personal (Garcia and Hardy, 2007). Research context: An Italian theater production

Organization and management scholars have turned to theater mostly to examine its organizational features from a structural perspective (e.g. Eikhof and Haunschild, 2007) or as a way to enhance corporate practices in traditional organizations (e.g. public speaking or teambuilding) (e.g. Koppett, 2013). However, knowledge on how theater workers generate meaning about their selves and work is limited. Thus, theater is a useful terrain to address debates in the literature on callings and identities, with previous studies confirming the considerable degree of meaning artists attach to their work, despite the precariousness of their occupation (Bain, 2005).

To understand how actors maintain a sense a calling in a precarious work setting, we selected a theater project in Italy. Access was negotiated by the lead author with a stage director who was gathering a group of professional actors. Being Italian and an actor prior to her academic career, she considered optimal accessing the industry in her home country and focus on a new production rather than on a repeated show. This was in order to appreciate the actors' dynamics in the early stage of their production. Furthermore, because access to a theater production is usually difficult due to the vulnerable and emotional nature of the artistic work involved, she turned to her established network of existing contacts and personal acquaintances. A semi-participatory approach was taken to this empirical investigation, meaning the lead author did not play 'an established participant role in the scene studied' (Atkinson and Hammersley, 1994: 248). Although she knew the director and most of the actors in the ensemble, she was not an active member of the theater group and did not help initiate or develop the artistic project. 
Contextual familiarity helped the first author recognize 'encounters, rituals and the story-telling' (Beech et al., 2012: 42) and prevented her from appearing out of context (Fontana and Frey, 2005). However, because of the familiarity with the empirical setting, reflexivity played a crucial role in directing the inquiry, as the researcher engaged in a continuous process of 'interpreting her own interpretations' (Alvesson and Sköldberg, 2000: vii). For example, after realizing that the informants were directing her attention in one way or another by confessing their frustrations with theater and the play, she employed strategies to avoid 'going native' (Tresch, 2001). By making observations from different places in the auditorium, she was able to interact with different informants, thereby ensuring that she did not become stuck within a particular spatial and cognitive perspective.

Over a four-week period of intensive rehearsals, the lead researcher shadowed the actors inside and around a private theater in Rome. The artistic ensemble included 21 experienced individuals who were active in the Italian theater circuit, including a stage director, an acting coach, a vocal coach, an assistant director and 18 actors (Table 1). The play was part of a broader artistic project to establish a new prose theater group to challenge the status quo of the Italian theater scene. The play was staged only once for the public to attract possible producers. At the time of the study, the actors had not received any pay for their work. They received the minimum salary for their work a year later, when the play was produced by the theater that had hosted the initial phase of rehearsals.

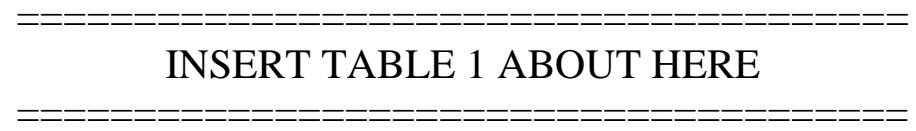

In the Western theater tradition, a professional actor is: 'Anyone who earns a living by being employed to perform in plays [and] anyone who has achieved a level of technical skill which enables [sic] to guarantee a certain quality of performance, no matter what the play or frequency of presentation' (Benedetti, 2012: 1-2). While many of the actors had small non- 
artistic jobs to supplement their theater incomes, they distinguished themselves from 'amateurs' because they were frequently employed and paid for their work in theater productions and were trying to make a living as artists.

\section{Data collection}

The aim of our data collection efforts was to access the linguistic and non-linguistic elements of human interactions via interviews and observations. The stories of theater professionals were collected primarily via in-depth conversational interviews (Holstein and Gubrium, 2004) conducted during rehearsals. The first author conducted 33 one-on-one interviews with the 21 informants at different stages during the four-week rehearsal period. These took place inside and outside the theater (main stage, small room, theater foyer and bar, a bar adjacent to the theater, a park and Skype). As detailed in Table 1, all of the theater professionals were interviewed at least once and 11 were interviewed a second time for clarification purposes. The participants were not specifically asked about calling, but they were asked open-ended questions such as 'Can you tell me about your decision to become an actor?' or 'Can you tell me about this project?' In answering, the informants talked about themselves, their work and the play. They reported facts and events, and expressed opinions, expectations and complaints, developing the narratives that we subsequently analyzed.

Observations were crucial for collecting additional information about how the actors generated and expressed the meaning of their work and their identities. Observations were made from different locations during formal encounters (on/off stage rehearsals and group meetings) and informal gatherings (bars, parks, restaurants). Over 320 hours of observations were documented in audio recordings and 35,476 words of field notes.

Data analysis

Inductive data analysis proceeded in three stages. First, the lead author fully transcribed the interviews verbatim in Italian and coded the full dataset (interview transcripts and field notes) 
in the original language to remain close to the data and minimize the loss of subtle linguistic elements. Using NVivo to perform relatively open coding (Corbin and Strauss, 1990), the author developed a data set of approximatively 800 codes containing key words, concepts and metaphors which were linked into meaningful constellations. During the coding process, two key themes emerged: first, the actors faced significant material and existential hardships as a result of their work; second, despite these hardships, the actors were unable to leave theater to pursue other occupational paths. While none of them directly used the Italian word for 'calling' (chiamata) during the interviews, the actors described their work as a 'deep and meaningful necessity', which is the definition of a calling. Hence, the focus on how actors maintained their calling in the face of hardships grew out of the data analysis.

Following the inductive analysis, the aim of the narrative analysis was to make sense of the stories organized around characters, events, experiences or actions, with a plot that tied together different parts in a meaningful whole (Czarniawska, 1998). A comparison of actors' stories revealed overlapping elements in how they made sense of their selves and their work situations. Using these elements, we constructed overarching composite narratives (Sonenshein, 2010) by organizing the fragmented and impartial accounts into a plot with characters and a timeline. In constructing the composite narratives, we also included the interviews with the assistant director and the vocal coach, for they also worked as actors in other productions and replaced the actors during these rehearsals.

The analytical process revealed three central narratives that all the actors drew upon as important resources in describing acting as a calling and how they deal with theater's precarious work situation. These 'religious', 'political' and 'therapeutic' (Table 2) narratives are based on broader public narratives (Somers, 1994) originating from the semantic fields of religion, politics and psychotherapy. Rather than defining these narratives in a strict sense (such as the religious story of Moses liberating the Jews), the composite narratives bring 
together words, metaphors and patterns that convey broad religious, political and therapeutic meanings derived from actors' efforts to make sense of themselves and the world they inhabit. As such, thsese narratives are not the interviewee's individual narratives. Rather, these are contextual narratives 'composed' through our analysis of how the theater actors as a cohort expressed who they are, their value judgements and their choices.

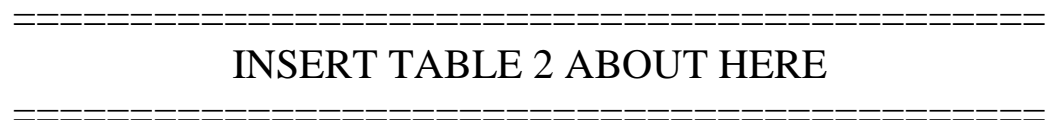

Although other contextual narratives might have been present, the religious, political and therapeutic narratives emerged with the most clarity in our theater setting. Each presents a beginning, a middle and an open ending, and shows how a calling is maintained in the face of hardships through different processes of identity work. Through data analysis, we clarified how actors employed the narratives to construct their role identities as 'martyrs' (religious), 'citizens' (political) and 'self-coaches' (therapeutic) through the identity work of sacrifice, responsibility and self-care which enabled them to narratively position themselves in relation to the other (Garcia and Hardy, 2007). Importantly, each of the narratives were not assigned to particular actors, as they all employed the three narratives at different times throughout the interviews. Upon completion of data analysis, the lead author translated the portions of the transcripts used to compose the overarching narratives into English. English being her second language, she validated the translations of the transcripts from Italian to English by working closely with one of the co-authors who is a native English speaker.

\section{The actor and the hardships of theater work}

Day 12. Today rehearsals start at $1 \mathrm{pm}$ on the main stage. I arrive to the theater at 12:35 pm. I enter the main stage and sit in silence in the stalls. I am alone. All the lights are 
down, apart from the ones on stage where Pasquale ${ }^{1}$ is setting the scene...At 12:50 pm the actors start populating the parterre in silence. They sit all over the stalls, either alone or in small groups. Pasquale continues setting the scene alone. It is 12:55 pm when the scene is ready, and Pasquale asks the actors to come closer to him. As the actors gather around him, he begins to speak slowly: 'You have very little energy, as a group, towards the work. Furthermore, you saw I was setting up the scene and you did not offer to help. This shows your weak interest in the work... This is not something done with the banal aim of simply going on stage to do a silly little performance... you must commit to this work and create a group, otherwise you look like many solitary individuals wandering on stage... You must have energy. We have the privilege of staging the play of an author who paid with his own life for his ideas, so if we decide to bring him on stage you must risk your own life - on stage, of course. You need to give all of yourself, completely, without thinking 'how boring' or 'I only have to say two lines and that actor has four'...You really need to give all of yourself, not because of the audience or certain critics...but because this is important. I am now in a difficult position.... and I feel awkward because I am reproaching you knowing that you are not getting paid. (Extract from field notes; Rome, 27 February 2015)

We include this prologue for three reasons. First, it provides some insights into the circumstances of the rehearsals. Second, it indicates the extent to which theater work should (or must) be understood and experienced by actors. Pasquale encouraged them to fully commit to their work because it is important, not because they must stage a 'silly little performance' for critics and an audience. That is, theater work is not just a job, but a calling. Pasquale reinforced this several times during his interview, when he claimed that 'the actor must have a deep necessity... a sort of primordial force [and] you know that you cannot do

\footnotetext{
${ }^{1}$ All names have been anonymized to protect informants' identities.
} 
other things than this, because theater is an illness' (emphasis added). All the actors also frequently used the term 'necessity'. For example, Salvatorina claimed that she has 'a deep necessity to give voice to the invisible people'. Finally, the prologue illustrates the hardships of artistic work. During the interviews, the actors shifted between expressing joy and gratitude for doing 'the most beautiful thing in the world' (Cramina), and exhaustion and anger over spending their lives engaged in a 'shitty occupation' (Eredina).

In theater work, material hardships are associated with low salaries, discontinuity in work practices, and a lack of clear work regulations. The poverty of most artists is widely recognized (Abbing, 2002), and some of the actors confessed to 'living at the border of poverty' (Augustina), while others claimed that 'to get paid in this job...one has to beg' (Nicola). Data from interviews and observations confirm that the actors were experiencing an ongoing sense of anxiety and frustration connected to their struggles around financial compensation and work continuity. Due to the uncertain and ephemeral nature of theater work, several actors experienced periods of unemployment, which they described as 'artistic darkness' (Pielle) or an 'artistic void' (Gaine). Even those who considered themselves well-established in the theater scene declared a 'lifelong precariousness' (Istevene). The limited financial resources allocated to culture led Pielle to define theater work as 'rubbish' and himself as 'oppressed by a system forcing me to be the slave of theatrical ideals written by the powerful'. The lack of regulations governing the actors' occupation was also a source of concern. Contracts within the industry were not taken seriously, 'because in theater, precariousness is even worse than in other jobs, since we can be dismissed at any time and for any silly reason' (Pressidia). Pielle portrayed actors as 'just interchangeable things', confessing he often finds himself in an uncomfortable position of fear because 'if I break a finger during rehearsals, for me it's the end. I am like a horse-I get shot and there's another one ready to take my place'. Overall, actors expressed 
anxiety over to the fact that 'from one day to the other you may stop working [and] you will not be able to bring home the daily bread' (Sidore).

Existential hardships are associated mainly with the struggle for social visibility and recognition. Actors feel rejected by others in society, and tend to distinguish 'us' (actors/artists) from 'them' (non-actors/artists), claiming society treats them 'just as folk attractions' (Nenna), 'timewasters, layabouts and buffoons' (Attilio), 'abnormal' (Sidore), or as 'people who don't work, don't want to work and don't know how to work' (Pielle). Nicola ascribed this aversion to the "negative and pretty generic view society has about the actor...that of the bohemian and reckless actor, negatively crazy'. During the interviews, the actors continuously questioned their occupational choices and identities. For example, they reflected upon the end of a production, describing it as 'a very delicate moment' (Cramina), where they return to the 'enduring waiting condition of getting another job' (Eredina). During this time, they feel 'out of balance...like in a seesaw' (Lussoria); 'empty, destabilized because a new existential crisis starts' (Sidore). Actors expressed these existential concerns when they tried to describe who they are and what they do. For example, Cramina said she feels 'ashamed every time I get paid to play', which is the fundamental pre-condition for a professional worker. During the interview, Mariano nervously exclaimed: 'I don't know if this is a job or not! I don't know what I am doing!'

Despite these hardships, nobody in the artistic ensemble seemed to be willing to give up theater work. The actors were well aware of this incongruence and admitted that 'at the end of the day, this motivation to quit is never completely true' (Pielle), because acting is a 'deep necessity of the self'-i.e. a personal calling. This calling is maintained through three narratives employed for identity work. Each narrative has a basic structure, with a beginning focused on how the actors got into theater, a middle with experienced hardships, and an open ending, with the possibility for a resolution. 


\section{The religious narrative}

The religious narrative begins with being drawn or converted to theater by a transcendent force. For example, Giovi was 'pushed by an irrational chthonian force'. For Eredina 'it was a matter of destiny', and Nenna 'felt literally struck on the Road to Damascus' the first time she did a theater workshop. Similar to how Saul the Pharisee, a persecutor of Christians, was blinded by Christ's light on the road to Damascus and converted to Christianity, thereby becoming Paul the Apostle, Nenna was struck by theater's light when she 'used to commute by tube to go to university' and saw 'normal people... with sad faces, going to work and back from work, with constrained lives, and constrained paths'.

These chosen ones heeded the call of theater and embarked on a thorny path wrought with hardships to pursue their mission 'to touch people's hearts' (Augustina), 'to guide the spectators towards catharsis' (Gaine), and to 'create beauty' (Mariano). The middle of this narrative reveals 'a human being in flesh and blood who makes a ritual for another human being' (Giovi); an individual 'who donates one's own feelings and body to others in service of others and humanity' (Minni). All respondents described theater as a 'sacred space' in which they pursue their work 'as a passion' (Peppa) despite hardships. Augustina explained that she 'turned down a three-month touring project, which meant money, in order to do this unpaid project [because] I decided to commit my life to a type of theater that talks to humans and God, and I am not interested in the little stories told to entertain'. She justified this decision based on an experience of theater as 'a deep necessity of the soul...a question of life or death, which I do not just to have a job...to clock in and out'. Similarly, Nicola referred to theater as 'a way to increase spirituality [since] theater permits inversion rather than diversion' (the English for divertire is 'to have fun'). In other words, the purpose of theater is to promote self-reflection, not simply to entertain. 
To maintain this view of theater work as a calling, the actors embraced sacrifices, renouncing material wealth and recognition:

I never question about where I will go with my work...I don't care if I am not recognized, because the most important thing in life is to cultivate myself...but this is a real sacrifice...Even if I am suffering, because I don't have any economic protection, once I am on stage, I tell myself, 'I give myself to console people's souls', and when I know people in the audience are touched by my acting, then every time I know that all my sacrifices are paid back. (Augustina)

For Augustina, to sacrifice is 'to live in a precarious way...never make long term plans, never go on holiday or go out to eat', and also 'feeling constant anxiety because I am never sure how I will survive next month'. Similarly, Mariano described how he maintains his calling through sacrifices:

I live like shit, in a condition of sub-humanity. I don't have a cent...I live like a nomad and I don't have a house, [but] I don't care about having certainties, having money or becoming rich... what's important are the certainties within yourself...Theater is a type of work that either you are really inclined to do because you have a deep necessity, or it is better if you do something else, a production, a job...for me it is an obsession that stays with me all the time.

To remain engaged with theater work, Mariano makes 'many sacrifices which I still do with pleasure'. For example, he is unable to travel 'because all the money I earn, I re-invest in art'. Whilst these actors were severely troubled by hardships, for some of the respondents, job precariousness functioned as an incentive to maintain their view of theater work as a calling. For example, Raimondo challenged the very basic conditions of work and employment, declaring, 'starvation helps because, through a lot of sacrifices you fight tooth and nail to achieve your dreams'. Importantly, the actors emphasized that they do not sacrifice just for the 
sake of sacrificing; rather, they sacrifice out of a sense of duty towards the 'other' as they pursue goals with higher ethical purposes than those who live mundane lives. This other, the interlocutor for whom the actors sacrifice, embodies the spiritually impoverished souls of contemporary capitalistic society, the infidels blinded by values of materiality, career and success who do not believe in the value of art as a way to ameliorate the human condition:

Every time I get on stage it's like I'm shouting to the audience...to those with sad faces going back and forth from work, 'Look! All this fire we have as human beings cannot be sedated!' It is like I am telling them, 'You can liberate yourself!' (Nenna)

As they pursue this calling, the actor-devotees aim to redeem the infidels of the consumer society through sacrifice. However, since there is always the possibility to sacrifice more or in different ways, the sacrifice is never fully complete-i.e. there is no narrative resolution.

\section{The political narrative}

The political narrative begins with a criticism of mainstream society: 'theater has to do with truth, with culture, things that are not given attention in our society' (Bellea). Nenna and Nicola described theater as 'a choice for freedom'. Far from being dogmatic, Nicola explained that freedom 'does not mean to do whatever you want, but to conduct a life free from the structures, constraints and norms imposed by society, religion, etc.'.

The actors described how engaging in theater work promotes increasing awareness of the political significance of theater as an ethical project and creates a 'deep necessity' to change the status quo of society. The middle of the political narrative outlines how an actor 'has great responsibilities in the way actions are carried out' (Gaine). Because 'theater is the mirror of society and it reflects society' (Augustina), actors have the responsibility 'to bring the others to themselves' (Bellea), by 'telling the truth to others' (Mariano) in order 'to awaken consciousness' (Pielle). Istevene clarified that although 'a country has never changed because of a single show...theater is still needed to adjust people's inner theater, to awaken and shape 
consciousness, to reorganize ideas, to allow self-knowledge'. To explain and substantiate the truth-telling role of theater and the actor, Nicola invoked the story of King Xerxes:

After being defeated by the Greeks, King Xerxes shut himself up within the Golden Palace of Susa in the Kingdom of Persia, to drink and have wild sex, as he was the richest king on earth...but he paid a slave to approach him, on a daily basis, and when he was in his happiest moments, to whisper in his ear, 'Sir, just remember that you have been defeated by the Greeks'.

In quoting Antonin Artaud, Nicola proudly exclaimed: 'This is the actor! A citizen educated to a principle of truth!'

The actors described how their engagement with theater work as a political project based on truth-telling is hindered by the hardships they face as they pursue their calling. Although 'theater is a very difficult job where there is little money', Sidore said he still wants to pursue acting because:

theater and the actor have a great responsibility to communicate and educate the masses... because after seeing a play someone may think, 'Ah, now I understand certain things... what I saw tonight may help me to change'.

The actors said that they maintain their work despite the hardships for the sake of truth-telling and education. Commenting on the unpaid project, Istevene said:

This is a political project...this means politics. It's not to say [with a resounding voice] 'I will chaaange!' But it is to say [with modesty] 'with our example, we work for a month and a half with no pay instead of staying home saying there are no jobs'... it's a way to break the chains...if we keep on reasoning in terms of [annoyed] career, money...I mean, either I change or there's nothing to do.

In maintaining their calling, the actors took political action by showing that achieving material stability and social recognition are secondary to the responsibility of emancipating society. 
This responsibility implies staying in touch with the 'real world' to awaken society. Although all of the actors expressed a desire to make a living in theater, instead of having to work as 'a hostess' (Peppa) or 'a stable boy' (Pielle), some viewed their engagement with non-artistic jobs as a way to stay connected with 'real life', thereby enabling them to enhance their artistic expression to foster societal emancipation. For example, Nicola said:

I cannot make a living only out of theater. I must work as a slave three times a week as a waiter in a restaurant...it's something to pay the bills but also something that allows me to step out the ivory tower of theater to do a type of work that puts me in touch with the real 'humus' of people (i.e. essence). Then I can use what I see there back on stage to foster my art...It's hard, but I cannot give up because theater is like the bees: they say that if the bees disappear the entire eco-system will collapse.

Similarly, Pressidia described how her work in a tobacco shop 'is something that allows me to see real life and then I can use what I see back on stage where I communicate something important'. Within the political narrative, the actors take responsibility for themselves and for the 'other': the thoughtless and irresponsible individuals who are not aware of the disciplinary and exploitative workings of the materialist consumer society:

I mean, again, the negative force of capitalism. When I was a child, I heard on tv there were so many people dying because of malaria around the world... Starvation killed millions of people... Now we have ultra-thin mobile phones, and we feel the necessity of silly things, surely useful, such as Facebook. But people keep on dying because of malaria and starvation. Why? Because capitalism has invested in the direction of profit, instead of life... That's why theater is important — to tell the truth-and it's a great responsibility. The problem is this: a marketing manager or someone similar is moved by that dark negative force, which is capitalism, the economic interest. 
The actors, often forced to work multiple jobs to pursue their artistic work, are aware of being exploited and consciously accept responsibility for sharing and spreading this truth by merging with the other to awaken society's collective consciousness and promote social change.

\section{The therapeutic narrative}

The therapeutic narrative begins with a personal problem addressed through engagement in theater, for example, to 'build more self-confidence, because I was bullied' (Raimondo) or 'to calm me down, as I was a hyperactive kid' (Gaine). In this narrative, theater is framed as a way to recover and healthe fragile and insecure self. It is in the convergence of well-being and distress that actors recognize the therapeutic side of theater. This narrative tells the story of an individual 'who grabs one's own wounds and transforms them into something else' (Giovi).

The creative process has to do with a very hard, frustrating and liberating process that makes the actor extremely vulnerable, that breaks down masks, and that exposes the person to self-judgments but also to external judgments...but it is also something very beautiful, because you get to know yourself. (Istevene)

The director plays a central role in this creative (therapeutic) process. Whilst not every stage director is considered a 'maestro', s/he provides the actors with the tools necessary to engage in deep self-reflection on the human experience. Sometimes this process can result in 'negative transfer'. The actors described stage directors 'who penetrated my soul like a hot knife into butter' (Nicola), and 'manipulated me and sucked my soul to foster his dark hole' (Istevene). Despite this vulnerability, they claimed that this creative process 'is the best part of this job, because you keep on discovering yourself and you always feel these emotions' (Eredina).

Similar to the other two narratives, the middle of the therapeutic narrative includes material and existential hardships. Citing the work by Luigi Pirandello, Bellea explained:

The fatigue I feel in this job does not come from the fact that I have to be One, No One and One Hundred Thousand on stage, but from the fact that I cannot concentrate only 
on theater and pure acting which makes me feel good, because I also have to do other small jobs in order to keep on doing this.

The actors maintained their calling by framing acting as a practice of self-care, and theater as a therapeutic space where they can satisfy an addiction to authentic experience. Lussoria explained: 'theater is authentic because it's that moment; you can do it right or wrong, but it's that moment. On stage you get the adrenaline and then you feel fulfilled'. The two interview passages below illustrate how actors prioritize the experience of real emotions and the development of 'authentic' selves over material security and social recognition:

I consider myself to be an actor, but there are times when I don't work and then I question whether I am an actor, because I cannot make a living out of this and I get help from my parents...but I accept this, because I cannot live without theater because it is an environment that pacifies me a lot...If I don't do theater, I feel bad. Therefore, I find myself in those situations where I agree to not be paid just for my wellbeing...I wouldn't be able to clock in and out every day. Monotony kills me...the office job, I mean, regularity. It really destroys your soul. (Forica)

Theater is a torture which I carry out with great obstinacy and willingness, because I have reached the age of 30 and I consider this to be my job, but at the same time I also consider this just an activity that feeds only my personal interest...it's good for me...only from a personal perspective, intimate, almost animal. I mean, like the lion goes hunting, I reach that thing and I feel better...The fact of staying nine hours, every day, inside an office...I can see I may be odd and insatiable, a dissatisfied person, whatever, but I don't feel like doing that...I get panic, angst...I want to be free...not doing theater, it would be like nullifying myself. (Pielle) 
The actors described theater as a form of self-care that enables them to remain authentic within an inauthentic (capitalistic) society. Nenna said: 'There are people who go back and forth to their offices without calling themselves into question...they live inauthentic lives...they aren't masters of their own destiny'. In contrast, she viewed her calling as authentic: 'I wanted to find my place in society, an authentic place where I can feel good, I can really be myself, where I can feel the emotions I need to feel'. During the interview, Nenna referred to the autobiographical movie Into the Wild: 'I mean, he left and went to Alaska...theater is my Alaska'. When Nenna was reminded that Christopher McCandless, the main character of the movie, paid for his choice to live authentically in nature with his own life, she answered:

True. In fact, theater is not an easy choice; but they will never have me, and I accept all of the consequences of this choice... if I am drained, I can work as a waitress for a bit...Maybe the choice of doing theater is a selfish one, but I do it because it makes me feel good.

Unlike the religious and political narratives, the therapeutic narrative tells a story of actors engaged in work as a form of self-care. The calling to theater is not a duty towards the other; it is an act of self-satisfaction and self-realization. Although the existence of the 'inauthentic' capitalistic society or other is acknowledged, in this narrative this other does not play a role in the calling.

\section{Calling and identity work}

The three narratives illustrate how actors maintain their callings despite material and existential hardships through different identity work processes and the enactment of different role identities. In the religious narrative, the actors cast themselves as sacrificial victims and bearers of a message to redeem the infidels. In the Christian doctrine, these two roles converge in the figure of the martyr, the person who testifies his/her faith despite persecution. This role is 
constructed via purifying identity work based on sacrifice. Actor-devotees who take a purist approach to theater reject the commercial aspects of their work and criticize framings of theater as 'entertainment' and 'fun'. Actors sacrifice the material stability and social recognition considered pivotal in capitalistic society to preserve their 'pure' work and artistic identities.

This calling emerges as an active response to societal norms rooted in capitalism whereby acting becomes a form of self-elevation towards a transcendental unity (i.e. God, the Divine, Dogma), reflecting a vertical movement away from society. To purify their identities, the actors seclude themselves within the ivory tower of theater, preaching and sharing their messages from behind an altar (the stage). The actors attempt to redeem the infidels' (consumers') souls without actually merging with them; rather, the other is kept at a distance and only engaged with indirectly. 'We are privileged; work is something else' (Nicola). Because this aristocratic ethical frame fosters a sense of elitism, exclusiveness and prestige, actors are willing to sacrifice to pursue their callings.

In the political narrative, the actors describe themselves as social actors who pursue theater as a political project to transform society. They maintain their calling and manage hardships by constructing the identity role of citizen of the democratic polis. This role is constructed through reconciling identity work based on the responsibility to take political action to emancipate society. By framing work as a responsibility, the actor-citizen adopts a pragmatic approach to theater work. 'One cannot remain pure. The system is this. It is not the box, the wrap, establishing whether you are doing art or not. You simply need to do your work with responsibility, without spitting in the plate where you're eating' (Istevene). They reconcile art with non-art, and the demands of 'dual lives' as they balance various part-time jobs with acting. Unlike the religious narrative, the political narrative highlights the more commercial aspect of work, artistic or otherwise. 
In reconciling art with non-art, the actors value educating and awakening the consciousness of thoughtless and irresponsible people over material stability and societal recognition. The other needs to know the truth about the exploitative workings of the capitalistic society - a truth of which the actors are well aware. In this narrative, actors engage with the other outside 'the ivory tower of art populated by prima donnas' (Nicola), unlike 'actors who enclose themselves in a bubble of fantasy and have no clue about reality' (Istevene). From this perspective, awakening society is only possible if actors stay in touch with the 'real world'. The political narrative frames theater as an act of resistance within capitalistic society, carried out by 'going into the real world to get [one's] hands dirty' (Pressidia). As such, this narrative reflects horizontal movement towards society. Even though the actors feel exploited, they recognize their condition and share this message with the other. In this narrative, 'actors are like other workers' (Gaine) and 'theater is a job like all the others' (Nenna). The populist ethical frame fosters a desire to achieve a sense of community; actorcitizens, who engage in reconciling identity work and adopt a sense of responsibility, resist by attempting to awaken the collective consciousness.

In the therapeutic narrative, the actors cast themselves as self-coaches. Theater enables fragile, insecure and tormented individuals to overcome personal hardships, be authentic and live better lives. This is accomplished via a process of self-questioning identity work based on self-care. In framing work as self-care, the self-coach manifests an existential approach to work by questioning the meaning of work and life; the relationship between art and non-art; and the nature of normality, stability and certainty. By engaging in a continuous process of selfexploration, self-knowledge and self-expression, actors pursue an authentic way of being.

In this narrative, the commercial aspects of work are neither completely rejected (religious), nor accepted (political), but opportunistically embraced to survive when artistic expression becomes upsetting. What matters is feeling good and remaining authentic within a 
largely inauthentic capitalistic society, where 'people are not masters of their own existences' (Nenna). Theater is meaningful as an emotional domain that enables actors to feel 'authentic', unlike the domain of traditional work. While the inauthentic other is acknowledged in identity work, the other is not engaged in the calling. The actors work to improve themselves because they cannot improve the world. As such, this narrative reflects circular movement around the self. The solution to human concern is to be found within the self. In the face of hardships encountered by actors, the therapeutic narrative exposes a bourgeois ethical frame substantiating the calling as an act of resilience of the (authentic) self within a largely (inauthentic) capitalistic society, where the ultimate telos is an authentic lifestyle.

\section{Discussion}

Our narrative analysis examined how callings are maintained in the precarious and artistic setting of theater. By addressing the call to investigate how people maintain callings (Duffy et al., 2016), we make three contributions. First, our analysis reveals critical insights into how calling is maintained despite obvious hardships (Dik et al., 2012; Bunderson and Thompson, 2009). Actors employ three different narratives as they engage in identity work, thereby generating 'deep' meaning about their work and moral identities (Wright et al., 2012). Through sacrifice, responsibility and self-care, the actors purify, reconcile and question their artistic work in relation to commercial aspects of both artistic and non-artistic work, and in relation to the materialistic and normative values of capitalistic society. Three contingent role identities (martyr, citizen and self-coach) based on different relationships to the other reveal how the actors maintain their callings despite significant hardships. Maintaining a calling emerges as contingently constructed acts of elevation, resistance and resilience that enable actors to achieve (a) a sense of elitism and prestige, (b) a sense of community, and (c) an authentic lifestyle. Thus, pursuing a calling can be seen as a form of identity work - a processual and 
dialogical movement (Beech, 2008) between individual circumstances and dominant public narratives.

In the setting of theater, the emergence of these three narratives is not surprising. In Ancient Greece, theater was established as a religious (pagan) rite, experienced as pharmakon, and embraced as a political event through which the agora was informed about the conduct of the governors of the polis in the form of either tragedy or comedy (Vernant, 1983). These three narratives continue to enable individuals to maintain their callings despite precarious work situations. These narratives are reinforced through identity work in the face of hardships, highlighting the importance of investigating contemporary organizations' encouragement of the pursuit of callings. Our evidence supports and adds nuance to previous findings that callings can be exploited (Berkelaar and Buzzanell, 2015). The three narratives expose three different rhetorics of exploitation: the rhetoric of sacrifice encourages people to struggle through poverty to reach one's dream; the rhetoric of responsibility substantiates the selfless citizen responsible for society; and rhetoric of self-care justifies working for free.

Second, our study contributes by enabling a refined understanding how a calling is maintained in relation to the other. The other is not just for comparison, as suggested in many studies on identity work (e.g. Clarke et al., 2009); rather, the ethical and social other imbues work with personal, moral and social significance (Rosso et al., 2010). Whilst this inquiry empirically substantiates research according to which 'duty towards the other' is central in pursuing one's calling (Bunderson and Thompson, 2009; Duffy et al., 2012), it augments this literature by exposing the different forms and extent of the other's engagement in the actor's calling. Both classical and neoclassical definitions of a calling emphasize duty towards the 'other' (e.g. saving animals or the planet), but it is unclear how and to what extent this 'other' plays a role in maintaining the framing of work as a calling. Our findings reveal the importance of the social dimension in the religious and political narratives, which frame theater work as a 
sacrifice for and responsibility towards the other. Engagement with the other is indirect (religious) or direct (political), revealing different relational distances to the social and ethical other. However, this engagement is replaced by comparison in the therapeutic narrative, which frames theater work as a self-care practice aimed at fostering personal wellbeing and authenticity relative to the other. This informs the tension between the social and the individual in the calling literature. In maintaining a calling through processes of narrative identity work, the actors revealed that precarious and ambiguous work situations involve ongoing trade-offs between the self and the other, between duty towards the other (classical calling) and duty towards the self (modern calling). The spotlight on the role of the other in a calling opens up space to examine how certain values are deprived of their ethical foundations in contemporary workplaces (Weber, 1930). Arguably, prominent neoliberal policy implementation encourages sacrifice and responsibility as fundamental values through which individuals achieve material prestige and social recognition, particularly in work contexts. However, without the duty towards the other, these values become self-referential, and perhaps empty.

Third, narrative identity work provides a theoretical explanation for why individuals pursue callings that extends current debates on how social actors try to resolve (or not) work identity tensions. Actors engage in the processes of purifying, reconciling and questioning their work identities at different narrative moments and with different purposes. In response to changing tensions and challenges in their work situations, an actor shifts between the narratives to construct a temporarily coherent self within a purposeful timeframe (Wright et al., 2012). This extends current discussions of how people draw on conflicting discourses (e.g. art and commerce) to construct themselves as ethical and moral beings in organizational settings.

The literature on identity work has shown that one's occupational identity may include antagonistic role identities (Clarke et al., 2009). Our study reveals this dialectic through three narratives that demonstrate how an individual enacts his or her identity and calling by 
continuously reframing his or her relationship to the other and conflicting principles. Importantly, while narratives play a crucial role in overcoming existential conflicts, the findings in this study indicate that conflicts are central to maintaining a calling and (artistic) identity. Overall, the actors' narrative identity work shows that a calling is multi-dimensional, with different cultural foundations (religious, political and therapeutic) guided by different values (sacrifice, responsibility, self-care) and purposes (elitism and prestige, sense of community, and authentic lifestyle), and different ethical frames (aristocratic, popular and bourgeois) and relationships to the other/self (vertical/elevating, horizontal/reconciling and circular/self-referential). In contemporary society, pursing a calling involves constantly shifting among acts of elevation, resistance and resilience.

\section{Conclusion}

Our theoretical explanation for how a calling is maintained has some practical implications. Theater actors who frame their work as a calling are subjected to forms of organizational exploitation; often, they work for a minimal salary, and sometimes even for free. The ambiguities of a calling with dimensions of sacrifice, responsibility and self-care place them at high risk for exploitation, which has practical implications for understanding the consequences of prominent managerial discourses that frame work as an act of self-fulfillment and selfinterest (Rose, 1999). Beyond the fine arts (e.g. opera, music, dance), this type of exploitation might be prevalent in other economically marginal, but symbolically significant settings (Bellah et al., 1985), such as non-profit and volunteer organizations, the public sector, education, and religious institutions.

The outcomes of this study open up avenues for future research. One would be to explore work as a calling in other precarious settings, given the idolized nature of work in the 'gig economy' (Petriglieri et al., 2017). Individuals who pursue callings need to be mindful of organizations' rhetorical strategies, which can legitimize and normalize precarious and 
ambiguous job practices. With this warning in mind, studies can be done to investigate how callings stratify societies (Berkelaar and Buzzanell, 2015), both in terms of (a) how the construction of a calling is used to exploit employees, and (b) how framing work as a calling becomes a means for sustaining societal inequalities. Finally, whilst the literature on callings has highlighted the hardships of discipleship (Bunderson and Thompson, 2009), the difference between hardships and costs seems conceptually and empirically blurred. We encourage researchers to investigate this relationship with particular attention to how hardships and costs emerge in different narrative or discursive structures.

\section{References}

Abbing H (2002) Why Are Artists Poor: The Exceptional Economy of the Art. Amsterdam: Amsterdam University Press.

Alvesson M and Karreman D (2004) Cages in tandem: Management control, social identity, and identification in knowledge-intensive firms. Organization 11(1): 149-75.

Alvesson M and Skölderberg K (2009) Reflexive Methodology: New Vistas for Qualitative Research. Thousand Oaks, CA: SAGE.

Alvesson M and Willmott $\mathrm{H}$ (2002) Producing the appropriate individual: Identity regulation as organizational control. Journal of Management Studies 39(5): 619-44.

Atkinson P and Hammersley M (1994) Ethnography and participant observation. In: Denzin NK, Lincoln YS (eds). Handbook of Qualitative Research. Thousand Oaks, CA: SAGE, 248-61.

Bain A (2005) Constructing an artistic identity. Work, Employment and Society 19(1): 25-46. Bamberg, M. (2009). Identity and Narration. Berlin: Walter de Gruyter.

Bardon T, Brown AD and Pezé S (2017) Identity regulation, identity work and phronesis. Human Relations 70(8): 1-26.

Baumeister RF (1991) Meanings of Life. London/New York: Guilford Press. 
Beech N (2008) On the nature of dialogic identity work. Organization (15)1: 51-74.

Beech N, Gilmore C, Cochrane E and Greig G (2012) Identity work as a response to tensions: A re-narration in opera rehearsals. Scandinavian Journal of Management 28(1): 39-47.

Beech N, Gilmore C, Hibbert P and Ybema S (2016) Identity-in-the-work and musicians' struggles: The production of self-questioning identity work. Work, Employment \& Society 30(3): 506-22.

Bell E, Taylor S and Driscoll C (2012) Varieties of organizational souls: The ethics of belief in organization. Organization 19(4): 425-39.

Bellah RN, Madsen R, Sullivan WM, Swidler A and Tipton SM (2007) Habits of the Heart: Individualism and Commitment in American Life. Berkeley, CA: University of California Press.

Benedetti J (2012) The Art of the Actor: The Essential History of Acting from Classical Times to Present Days. London: Routledge.

Berkelaar BL and Buzzanell PM (2015) Bait and switch or double-edged sword? The (sometimes) failed promises of calling. Human Relations 68(1): 157-78.

Boje DM (2011) Storytelling and the Future of Organizations: An Antenarrative Handbook. London: Routledge.

Brown AD (2015) Identities and identity work in organizations. International Journal of Management Reviews 17: 20-40.

Bruner J (1994) The Remembering Self: Construction and Accuracy in the Self Narrative. Cambridge: Cambridge University Press.

Bunderson JS and Thompson JA (2009) The Call of the Wild: Zookeepers, Callings, and the Double-edged Sword of Deeply Meaningful Work. Administrative Science Quarterly 54(1): 32-57. 
Cardador MT and Caza BB (2012) Relational and identity perspectives on healthy versus unhealthy pursuit of callings. Journal of Career Assessment 20(3): 338-53.

Clarke CA, Brown AD and Hailey VH (2009) Working identities? Antagonistic discursive resources and managerial identity. Human Relations 62(3): 323-52.

Collinson LD (2003) Identities and insecurities: Selves at work. Organization 10(3): 527-47.

Corbin J and Strauss A (1990) Basics of Qualitative Research: Grounded Theory Procedures and Techniques. Newbury Park, CA: SAGE.

Czarniawska B (1998) A Narrative Approach to Organization Studies. Thousand Oaks, CA: SAGE.

Dawson J (2005) A history of vocation: Tracing a keyword of work, meaning, and moral purpose. Adult Education Quarterly 55(3): 220-31.

Dik BJ and Duffy RD (2009) Calling and vocation at work: Definitions and prospects for research and practice, The Counseling Psychologist 37: 424-50.

Dik BJ and Shimizu BA (2018) Multiple meanings of calling: Next steps for studying an evolving construct. Journal of Career Assessment 27(2): 1-14.

Duffy RD, Foley PF, Raque-Bodgan TL, Reid-Marks L, Dik BJ et al. (2012) Counseling psychologists who view their careers as a calling: A qualitative study. Journal of Career Assessment 20(3): 293-308.

Duffy DR and Dik BJ (2013) Research on calling: What have we learned and where are we going? Journal of Vocational Behavior 83(3): 428-36.

Duffy DR, Douglass RP, Autin KL, England J and Dik BJ (2016) Does the dark side of a calling exist? Examining potential negative effects. Journal of Positive Psychology 11(6): 634-646.

Eikhof DR and Haunschild A (2007) 'For art's sake! Artistic and economic logics in creative production'. Journal of Organizational Behavior 28: 523-538. 
Elangovan AR, Pinder CC and McLean M (2010) Callings and organizational behavior. Journal of Vocational Behaviour 76: 428-40.

Fleming P (2009) Authenticity and the Cultural Politics of Work: New Forms of Informal Control. Oxford: Oxford University Press.

Fontana A and Frey JH (2005) The interview: From neutral stance to political involvement. In: Denzin NK, Lincoln YS (eds) The SAGE Handbook of Qualitative Research. Thousand Oaks, CA: SAGE.

Garcia P and Hardy C (2007) Positioning, similarity and difference: Narratives of individual and organizational identities in an Australian university. Scandinavian Journal of Management 23: 363-83.

Hall DT and Chandler DE (2005) Psychological success: When the career is a calling. Journal of Organizational Behavior 26(2): 155-76.

Hardy L (1990) The Fabric of this World: Inquiries into Calling, Career Choice and the Design of Human Work. Grand Rapids, MI: Wm B Eerdmans.

Heelas P. (2002). Work ethics, soft capitalism and the 'turn to life'. Cultural Economy 78-96.

Hirschi A (2011) Callings in career: A typological approach to essential and optional components. Journal of Vocational Behaviour 79: 60-73.

Holstein JA and Gubrium JF (2004) The Active Interview. Thousand Oaks, CA: SAGE.

Huber G and Brown AD (2017) Identity work, humour and disciplinary power. Organization Studies 38(8): 1107-26.

Kim SS, Shin D, Vough CH, Hewlin FP and Vandenbergh C (2018) How do callings relate to job performance? The role of organizational commitment and ideological contract fulfilment. Human Relations 7(10): 1319-47. 
Koppett K. (2013) Training to imagine: Practical improvisational theatre techniques for trainers and managers to enhance creativity, teamwork, leadership, and learning. Stylus publishing.

Lips-Wiersma, M. \& Morris, L. (2009). Discriminating between 'meaningful work'and the 'management of meaning'. Journal of Business Ethics, 88, 491-511.

Madden A, Bailey C and Reverend Kerr JC (2015) 'For this I was made': Conflict and calling in the role of a woman priest. Work, Employment and Society 29(5): 866-74.

Michaelson C and Tosti-Kharas J (2019) Serving self or serving others? Close relations' perspectives on ethics and calling. Journal of Vocational Behavior 114: 19-30.

Novak M (1996) Business as a Calling: Work and the Examined Life. New York: Free Press.

Nyberg D and Sveningsson S (2014) Paradoxes of authentic leadership: Leader identity struggles. Leadership 10(4): 437-55.

Petriglieri G, Ashford SJ and Wrzesniewski A (2017) Agony and ecstasy in the gig economy: Cultivating holding environments for precarious and personalized work identities. Administrative Science Quarterly 64(1): 124-70.

Ricoeur P (1991) Narrative identity. Philosophy Today 35: 73-81.

Ricoeur P (1984) Time and Narrative. Chicago: University of Chicago Press.

Riessman CK (2008) Narrative Methods for the Human Sciences. Thousand Oaks, CA: SAGE. Rose N (1999). Governing the Soul: The Shaping of the Private Self. London: Routledge.

Rosso BD, Dekas KH and Wrzesniewski A (2010) On the meaning of work: A theoretical integration and review. Research in Organizational Behavior 30: 91-127.

Schabram K and Maitlis S (2017) Negotiating the challenges of a calling: Emotion and enacted sensemaking in animal shelter work. Academy of Management Journal 60: 584-609.

Somers MR (1994) The narrative constitution of identity: A relational and network approach. Theory and Society 23: 605-49. 
Sonenshein S (2010) We're changing - or are we? Untangling the role of progressive, regressive, and stability narratives during strategic change implementation. Academy of Management Journal 53(3): 477-512.

Steger MF, Pickering N, Shin JY and Dik BJ (2010). Calling in work: Secular or sacred? Journal of Career Assessment 18: 82-96.

Sveningsson S and Alvesson M (2003) Managing managerial identities: Organizational fragmentation, discourse and identity struggle. Human Relations 56(10): 1163-93.

Thornborrow and Brown (2009) 'Being regimented': Aspiration, discipline and identity work in the British parachute regiment. Organization Studies 30(4): 355-76.

Tresch J (2001) On going native: Thomas Kuhn and anthropological method. Philosophy of the Social Sciences 31(3): 302-22.

Van Maanen J (1988) Tales of the Field: On Writing Ethnography. Chicago: University of Chicago Press.

Vernant JP (1983) Myths and Thought among the Greeks. Brooklyn, NY: Zone Books.

Weber M (1930) The Protestant Ethic and the Spirit of Capitalism. Parson T (trans). London: Allen and Unwin.

Watson TJ (2008) Managing identity: Identity work, personal predicaments and structural circumstances. Organization 15(1): 121-43.

Weick KE (1985) Sensemaking in Organizations. Thousand Oaks, CA: SAGE.

Wright C, Nyberg D and Grant D (2012) 'Hippies on the third floor': Climate change, narrative identity and the micro-politics of corporate environmentalism. Organization Studies 33(11): 1451-75.

Wrzesniewski, A. (2003). Finding positive meaning in work. In Cameron KS, Dutton JE and Quinn RE (eds) Positive Organizational Scholarship. San Francisco: Berrett-Koehler. 
Wrzesniewski A, McCauley C, Rozin P and Schwartz B (1997) Jobs, careers, and callings: People's relations to their work. Journal of Research in Personality 31: 21-33.

Table 1. Interview respondents

\begin{tabular}{|c|c|c|c|c|c|c|c|}
\hline Respondent & Role & Other job(s) & Gender & Age & $\begin{array}{c}\text { No. of } \\
\text { Interviews }\end{array}$ & Duration & Type \\
\hline Pasquale & Stage director & - & Male & $40-50$ & 1 & $59^{\prime}$ & In person \\
\hline Attilio & Assistant director & Hospitality & Male & $35-40$ & 1 & $122^{\prime}$ & Skype \\
\hline Giovi & Acting coach & Hospitality & Female & $40-50$ & 1 & $733^{\prime}$ & In person \\
\hline Istevene & Actor & - & Male & $30-35$ & 3 & $62^{\prime}$ & In person \\
\hline Gaine & Actor & Various others & Male & $25-30$ & 1 & $57^{\prime}$ & In person \\
\hline Lussoria & Actor & - & Female & $30-35$ & 2 & $41^{\prime}$ & In person \\
\hline Eredina & Actor & Hospitality & Female & $30-35$ & 2 & $79^{\prime}$ & In person \\
\hline Nenna & Actor & Hospitality & Female & $30-35$ & 1 & $64^{\prime}$ & In person \\
\hline Mariano & Actor & Various others & Male & $30-35$ & 2 & $68^{\prime}$ & In person \\
\hline Forica & Actor & - & Female & $30-35$ & 2 & 50 & In person \\
\hline Sidore & Actor & - & Male & $35-40$ & 2 & $98^{\prime}$ & $\begin{array}{c}\text { In person/ } \\
\text { Skype }\end{array}$ \\
\hline Pielle & Actor & Media/others & Male & $25-30$ & 2 & $81^{\prime}$ & In person \\
\hline Augustina & Actor & Hospitality & Female & $30-35$ & 3 & $102^{\prime}$ & In person \\
\hline Nicola & Actor & Hospitality/other & Male & $25-30$ & 1 & $63^{\prime}$ & In person \\
\hline Salvatorina & Actor & - & Female & $30-35$ & 1 & $69^{\prime}$ & In person \\
\hline Raimondo & Actor & Media & Male & $25-30$ & 1 & $27^{\prime}$ & In person \\
\hline Bellea & Actor & - & Female & $30-35$ & 1 & $54^{\prime}$ & In person \\
\hline Peppa & Actor & Hospitality/retail & Female & $35-40$ & 2 & $59^{\prime}$ & In person \\
\hline Minni & Actor & - & Male & $30-35$ & 1 & 124 & Skype \\
\hline Cramina & Actor & - & Female & $25-30$ & 2 & $49^{\prime}$ & In person \\
\hline Pressedia & Actor & Retail/media & Female & $30-35$ & 2 & $59^{\prime}$ & In person \\
\hline
\end{tabular}

Note: Names have been changed to protect the anonymity of the interviewees. 


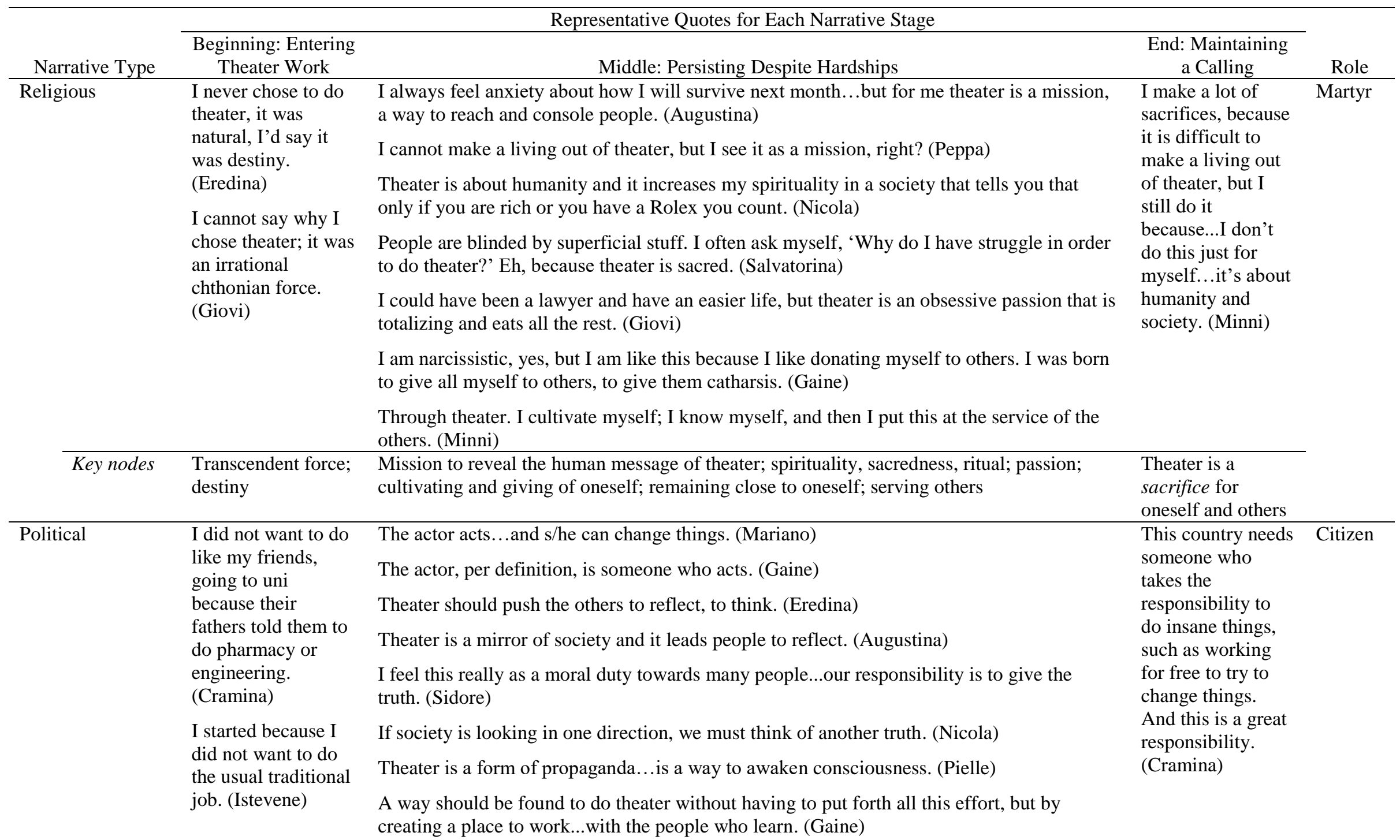




\begin{tabular}{|c|c|c|c|c|}
\hline Key nodes & $\begin{array}{l}\text { Critique of } \\
\text { mainstream society }\end{array}$ & $\begin{array}{l}\text { Stimulating action and change as a form of emancipation; prompting reflection via } \\
\text { communication; telling the truth to others; awakening the collective consciousness; } \\
\text { educating }\end{array}$ & $\begin{array}{l}\text { Theater is a } \\
\text { responsibility to } \\
\text { oneself and others }\end{array}$ & \\
\hline Therapeutic & $\begin{array}{l}\text { As a kid I was } \\
\text { bullied...I needed } \\
\text { to build more self- } \\
\text { confidence. } \\
\text { (Raimondo) } \\
\text { I started theater to } \\
\text { pacify my restless } \\
\text { self, as I was } \\
\text { overwhelmed by } \\
\text { feelings of rage and } \\
\text { anxiety. (Nicola) }\end{array}$ & $\begin{array}{l}\text { Theater is authentic because it's that moment; you can do it right or wrong, but it's that } \\
\text { moment and that creates the adrenaline (Lussoria) } \\
\text { This is a type of work that allows me to be authentic. (Nenna) } \\
\text { When you finish a production, you feel empty....and a new crisis starts. (Sidore) } \\
\text { In theater you feel vulnerable because you expose yourself...more than astonishment, in } \\
\text { theater one feels the taste of fear, because you get to know yourself and this is destabilizing. } \\
\text { (Istevene) } \\
\text { I will always be grateful to my maestro because he allowed to me overcome the biggest } \\
\text { pains and sorrows in my life. (Nicola) } \\
\text { My maestro has taught me we actors are a bit bipolar. (Salvatorina) } \\
\text { I could not stay away from theater, and I returned because theater allowed me to know } \\
\text { myself and it simply was a better way of living. (Attilio) } \\
\text { Theater is extremely exhausting because you always need to explore yourself, know } \\
\text { yourself. This can be painful but it's actually the best part. (Eredina) } \\
\text { Theater as a path to authenticity; crisis, destabilization, vulnerability; existential concerns } \\
\text { stemming from the artistic craft and job; maestro/stage director provides actors with the } \\
\text { tools for deep self-reflection; theater is a way to engage in in-depth self-exploration and } \\
\text { self-knowledge }\end{array}$ & $\begin{array}{l}\text { Theater is not a } \\
\text { type of work better } \\
\text { than another. It is } \\
\text { a way to live a } \\
\text { better life, to feel } \\
\text { better. (Mariano) }\end{array}$ & $\begin{array}{l}\text { Self- } \\
\text { coach }\end{array}$ \\
\hline
\end{tabular}

